\section{An Efficient Tissue Culture Regeneration System for Georgia Plume, Elliottia racemosa, a Threatened Georgia Endemic}

\author{
Seong Min Woo and Hazel Y. Wetzstein ${ }^{1}$ \\ Department of Horticulture, University of Georgia, 1111 Miller Plant \\ Science Building, Athens, GA 30602-7273
}

Additional index words. adventitious shoots, conservation, micropropagation, organogenesis, rooting

\begin{abstract}
Georgia plume, Elliottia racemosa Muhlenb. ex. Elliott, is an extremely rare small tree or shrub endemic to Georgia, which is being severely affected by habitat loss and lack of sexual recruitment. In vitro plant regeneration of Georgia plume has not been previously reported and may be a method for the conservation and propagation of this threatened species. Studies evaluated the effects of sterilization methods, explant types, medium composition, and light environment on plant regeneration. An efficient plant regeneration system was developed in which adventitious shoot buds were induced using young, expanding leaf explants placed on an induction medium supplemented with $10 \mu_{M}$ thidiazuron and $5 \mu M$ indole-3-acetic acid with Gamborg's $B_{5}$ salts. Shoot elongation was promoted on a medium with $25 \mu \mathrm{M}$ (2-isopentenyl) adenine incorporated into Woody Plant Medium. In vitro rooting studies evaluated continuous and pulse auxin treatments and ex vitro rooting trials after KIBA (indole-3-butric acid, potassium salt) dips. A 5-day pulse treatment on 100 or $150 \mu \mathrm{M}$ indole-3-butyric acid produced $\approx 90 \%$ rooting of shoots with greater shoot and root dry weight than other pulse times. High rooting frequencies were obtained under in vitro and ex vitro conditions with over $85 \%$ survival of plantlets transferred to greenhouse conditions. The culture protocol was found to be effective with material collected from mature specimens in the wild from divergent populations. Tissue culture appears to be a promising approach for the propagation and conservation of this rare and threatened plant.
\end{abstract}

Elliottia racemosa, classified within the group of the Ericaceae family, is one of the rarest native small trees or large shrubs in Georgia and is a state threatened shrub (Chafin, 2007). Elliottia racemosa, commonly called Georgia plume, derives its name from the beautiful plume-like clusters of slightly aromatic white flowers that appear in early summer (Elliott, 1971). Georgia plume is a beautiful deciduous shrub reaching heights of 20 feet tall with leaves that are elliptic, alternate, 2.5 to $12.7 \mathrm{~cm}$ long by 1.3 to $5 \mathrm{~cm}$ wide, and tapering at both ends. Flowers have four or five curved white petals each growing up to $14 \mathrm{~mm}$ long, which appear between the middle of June and end of July (Patrick et al., 1995). The flowers develop into small round capsules, which can contain up to $\approx 40$ seeds.

Georgia plume was first discovered by William Bartram in 1773 and not collected again until it was found by South Carolina botanist Stephen Elliot 35 years later (Ewan, 1968; Patrick et al., 1995). Attesting to the rarity of the species, no wild populations were known to science after $\approx 1875$ until it

Received for publication 12 Sept. 2007. Accepted for publication 8 Dec. 2007.

We thank Gwen Hirsch for her technical assistance. ${ }^{1}$ To whom reprint requests should be addressed; e-mail hywetz@uga.edu was rediscovered in 1901. Many of the known populations are now destroyed or very reduced with few on conservation land (Chafin, 2007). Today, E. racemosa is found only in $\approx 36$ locations in the state of Georgia (Patrick et al., 1995). The best habitats generally seem to be sunny to partially shady conditions on well-drained sand ridges, oak ridges, evergreen hammocks, acid soil, and sandstone outcrops. Although this plant is very rare and localized, it grows in a broad variety of sandy soil conditions ranging from moist to extremely dry (Patrick et al., 1995).

Bozeman and Roger (1983) reported that natural seed set in Georgia plume is limited or nonexistent. Recent seedling recruitment has not been documented in any populations (Godt and Hamrick, 1999). Contributing factors may include self-incompatibility, low pollen viability, and limited numbers of clones within locations (Godt and Hamrick, 1999; Thompson and Spira, 1991). Some plants show multiple trunks owing to vegetative root sprouting after injury such as cutting or fire indicating extensive clonal growth occurs. However, the biological cycle and life history of Georgia plume is not well reported or understood.

Efforts to propagate Georgia plume using conventional methods have been generally ineffective. Fordham (1969) obtained limited success with seed germination. The problem was that only a small percentage of seed was sound. Seed stratification removed a cold requirement, but only if given to seed treated within a few months of collection. Old seed acquired secondary dormancy and unpredictable behavior (Fordham, 1969). Fordham (1991) determined that Georgia plume's seed dormancy mechanism required a prolonged chilling period ( 42 to $64 \mathrm{~d}$ ) for germination. Propagation by root cutting methods can produce shoots, but in a limited number.

Tissue culture methods can be an excellent option for the propagation and conservation of threatened or endangered species because small amounts of tissues can be used for mass propagation without damage to the donor (Varadaragan, 1993). A large number of plants may be produced in a given time, and little space is required for tissue culture compared with other propagation methods (Fay, 1992). It is also possible to maintain large genotypic libraries of selected species for plant conservation.

The Ericaceae contains a number of economically important plants such as blueberry, cranberry, and rhododendron. This has led to the development of efficient plant regeneration protocols achieved through organogenesis from cultures derived from leaf tissue, shoot tips, and axillary buds. Plants regenerated from this family include blueberry (Billings et al., 1988; Callow et al., 1989; Cao and Hammerschlag, 2000; Hruskoci and Read, 1993), cranberry (Debnath and McRae, 2001b; Qu et al., 2000), lingonberry (Debnath, 2003; Debnath and McRae, 2002), blackberry (Gonzalez et al., 2000), and rhododendron (Iapichino et al., 1992; Meyer, 1982).

A number of endangered species have been successfully regenerated using in vitro culture methods. For example, rapid multiplication of Blue Vanda of Asia (Vanda coerulea Griff ex. Lindl.) was accomplished using shoot tips, leaves, and leaf bases (Seeni and Latha, 2000). After plant regeneration, plantlets were successfully reintroduced into alien forest habitats. Mass propagation protocols for Vaccinium cylindraceum Smith (Ericaceae) (Pereira, 2006), Maclura tinctoria (Gomes et al., 2003), Vanda coerulea (Malabadi et al., 2004), and Daphne cneorum (Mala and Bylinsky, 2004) were successfully achieved.

In vitro plant regeneration of Georgia plume has not been previously reported and may be a method for the conservation and propagation of this threatened species. The overall goal of this study was to develop tissue culture protocols for the mass propagation of Elliottia racemosa, Georgia plume, applicable for conservation purposes. Objectives of the work include the development of efficient sterilization conditions for initiation of cultures and the development of protocols for shoot proliferation, rooting, and acclimatization of plants.

\section{Materials and Methods}

Plant materials. Plant materials used in studies were from natural collections and greenhouse plants. In September, plant 
material, consisting of leaves and buds of the apical 3 to $7 \mathrm{~cm}$ of actively growing shoots, was collected in situ from mature populations at the Charles Harrold Preserve, Statesboro, GA. On return to the laboratory, leaf and bud tissues were dissected and explanted onto appropriate media. In addition, root cuttings of field material were collected, planted into potting mix (Fafard 3B; Conrad Fafard, Agawam, MA), and placed under mist. Root pieces less than $1 \mathrm{~cm}$ in diameter were placed horizontally, whereas larger pieces were planted vertically. Adventitious shoots emerged, which provided additional leaf tissue for explanting. Some plants were obtained from collections of the Georgia Southern Botanical Garden, Statesboro, GA, and maintained in the University of Georgia Horticulture greenhouses.

Disinfection. For decontamination before introduction into sterile culture, explants from the field and greenhouse were given sterilization treatments in which tissues were sequentially submerged for different times and with varying concentrations of ethanol, Roccal (a quarternary ammonium disinfectant; National Laboratories, Montvale, NJ), then $\mathrm{NaOCl}$ as indicated in Table 1. Tissues were subsequently rinsed three times with sterile, distilled water for $5 \mathrm{~min}$ each rinse. Explant tissues included: 1) young leaves, less than $2 \mathrm{~cm}$ long, yellow green color; 2) older but still elongating leaves, 2 to $7 \mathrm{~cm}$ long, light green color; and 3) axillary buds. Leaf explants were cut into pieces $\approx 5 \mathrm{~mm}^{2}$. Before disinfection, buds were dissected to remove bud scales and older leaf primordia. After sterilization treatments, tissues were placed onto shoot induction medium with thidiazuron (TDZ) plus indole-3-acetic acid (IAA) as described subsequently in $25 \times 150$ $\mathrm{mm}$ test tubes with $20 \mathrm{~mL}$ of medium per tube. After 4 weeks, cultures were assessed for contamination and injury. For experiments with different explant tissues, each sterilization treatment consisted of at least 40 explants. The experiments were repeated three times with leaf tissue. Cultures were observed every $2 \mathrm{~d}$ with final observations recorded after 4 weeks.

Shoot induction. Shoot induction studies were conducted using buds and leaf tissues of two ages placed on media supplemented with either 2iP (Callow et al., 1989) or TDZ in combination with IAA (Anthony, 2004). These media were chosen because they induced successful shoot proliferation or somatic embryogenesis in related species. TDZ medium consisted of $10 \mu \mathrm{M}$ TDZ, 5 $\mu \mathrm{M}$ IAA, $10 \mathrm{mg} \cdot \mathrm{L}^{-1}$ thiamine $\mathrm{HCl}, 1 \mathrm{mg} \cdot \mathrm{L}^{-1}$ pyridoxine, $1 \mathrm{mg} \cdot \mathrm{L}^{-1}$ nicotinic acid, $40 \mathrm{~g} \cdot \mathrm{L}^{-1}$ maltose, and $4 \mathrm{~g} \cdot \mathrm{L}^{-1}$ Gel-Gro (ICN Biochemicals, Aurora, OH), with Gamborg's $\mathrm{B}_{5}$ salts $\left(\mathrm{GB}_{5}\right)$ (Gamborg et al., 1968). The $\mathrm{pH}$ was adjusted to 6.0 before autoclaving at $121{ }^{\circ} \mathrm{C}$ for $20 \mathrm{~min}$. Media with $25 \mu \mathrm{M} 2 \mathrm{iP}$ were supplemented with $2 \mathrm{mg} \cdot \mathrm{L}^{-1}$ glycine, 0.5 $\mathrm{mg} \cdot \mathrm{L}^{-1}$ nicotinic acid, $0.5 \mathrm{mg} \cdot \mathrm{L}^{-1}$ pyridoxine $\mathrm{HCl}, 1 \mathrm{mg} \cdot \mathrm{L}^{-1}$ thiamine $\mathrm{HCl}, 100 \mathrm{mg} \cdot \mathrm{L}^{-1}$ myo-inositol, $20 \mathrm{~g} \cdot \mathrm{L}^{-1}$ sucrose, and $4 \mathrm{~g} \cdot \mathrm{L}^{-1}$ Gel-Gro with Woody Plant Medium (WPM) (Lloyd and McCown, 1980) with the $\mathrm{pH}$ adjusted to 5.2. Young leaves, older leaves, and bud explants were prepared as described in sterilization studies. Leaves were placed horizontally with the abaxial leaf surface in contact with the medium. Explants were initially placed into test tubes with $20 \mathrm{~mL}$ medium per tube and then after 4 weeks transferred onto the same medium in $5.5 \times$ 6-cm baby food jars ( $30 \mathrm{~mL}$ medium per jar). All explants were cultured either under continuous dark conditions or a 16-h photoperiod (white fluorescent lights at $70 \mu \mathrm{mol} \cdot \mathrm{m}^{-2} \cdot \mathrm{s}^{-1}$ ) at $25^{\circ} \mathrm{C}$. Forty cultures per explant type and light condition were evaluated.
Further studies were conducted to evaluate the long-term maintenance of shoot clumps obtained from induction studies. Because continued production of adventitious shoots is important for in vitro mass propagation, secondary media conditions were evaluated to identify plant growth regulator concentrations promoting continued adventitious shoot formation. Shoot bud cultures previously induced on $\mathrm{GB}_{5}$ medium with $10 \mu \mathrm{M}$ TDZ plus $5 \mu \mathrm{M}$ IAA for 3 months were transferred onto media with: 1) no plant growth regulator; 2) half-strength plant growth regulator concentration $(5 \mu \mathrm{M}$ TDZ and $2.5 \mu \mathrm{M}$ IAA); or 3 ) the same plant growth regulator concentration $(10 \mu \mathrm{M} \mathrm{TDZ}$ and $5 \mu \mathrm{M}$ IAA). From 40 to 48 shoot clumps were cultured per treatment. Cultures were maintained on their respective media for 3 months under a 16 -h photoperiod as described previously. The study was repeated twice.

Shoot elongation. Shoot clumps obtained on induction medium with TDZ and IAA were prolific but required elongation before shoots could be manipulated for plant regeneration. To promote shoot elongation, shoot clumps were divided into pieces $\approx 10 \mathrm{~mm}^{2}$ wide and transferred onto WPM containing $25 \mu \mathrm{M} 2 \mathrm{iP}$ in baby food jars with $30 \mathrm{~mL}$ per jar. Shoot clumps were obtained from previous studies, which were induced under either dark or light conditions. Four shoot clumps were cultured per baby food jar, and 120 shoot clumps were used per treatment. All cultures were maintained under white fluorescent lights $\left(70 \mu \mathrm{mol} \cdot \mathrm{m}^{-2} \cdot \mathrm{s}^{-1}\right)$ at $25^{\circ} \mathrm{C}$ and subcultured onto the same medium every 4 weeks. Cultures were scored for the presence of buds versus elongated foliar shoots after 4 and 8 weeks on elongation treatments. The experiment was repeated three times.

Rooting. Root induction studies were conducted using various types and concentrations

Table 1. Contamination, injury, and healthy cultures obtained with field or greenhouse Elliottia racemosa tissues of different ages using various sterilization protocols. ${ }^{2}$

\begin{tabular}{|c|c|c|c|c|c|c|c|c|}
\hline \multirow[b]{2}{*}{ Explant } & \multirow{2}{*}{$\begin{array}{c}70 \% \mathrm{EtOH} \\
\mathrm{Sec}\end{array}$} & \multicolumn{2}{|c|}{ Roccal } & \multicolumn{2}{|c|}{$\mathrm{NaOCl}$} & \multirow{2}{*}{$\begin{array}{c}\text { Contaminated } \\
(\%)\end{array}$} & \multirow{2}{*}{$\begin{array}{l}\text { Injured }^{y} \\
(\%)\end{array}$} & \multirow{2}{*}{$\begin{array}{c}\text { Healthy cultures } \\
(\%)\end{array}$} \\
\hline & & $\%$ & Min & $\%$ & Min & & & \\
\hline Leaf & 30 & - & - & 0.6 & 10 & $99 \mathrm{a}^{\mathrm{x}}$ & $1 \mathrm{c}$ & $0 \mathrm{~b}$ \\
\hline Leaf & 30 & - & - & 1.2 & 10 & $96 \mathrm{a}$ & $4 \mathrm{c}$ & $0 \mathrm{~b}$ \\
\hline Leaf & 60 & 10 & 10 & 1.2 & 10 & $43 \mathrm{c}$ & $38 \mathrm{a}$ & $19 \mathrm{a}$ \\
\hline Bud & 60 & 10 & 10 & 0.6 & 10 & $100 \mathrm{a}$ & $0 \mathrm{~b}$ & $0 \mathrm{~b}$ \\
\hline Bud & 60 & 10 & 10 & 1.2 & 10 & $100 \mathrm{a}$ & $0 \mathrm{~b}$ & $0 \mathrm{~b}$ \\
\hline \multicolumn{9}{|c|}{ Greenhouse material } \\
\hline Leaf $(\mathrm{O})^{\mathrm{w}}$ & 60 & - & - & 1.2 & 10 & $41 \mathrm{~cd}$ & $24 \mathrm{bc}$ & $35 \mathrm{~d}$ \\
\hline Leaf (O) & 60 & 5 & 5 & 0.6 & 10 & $37 \mathrm{~cd}$ & $19 \mathrm{bc}$ & $44 \mathrm{~cd}$ \\
\hline Leaf $(\mathrm{O})$ & 60 & 10 & 10 & 0.6 & 10 & 30 cde & $24 \mathrm{bc}$ & $46 \mathrm{~cd}$ \\
\hline Leaf $(\mathrm{O})$ & 60 & 20 & 10 & 1.2 & 10 & $27 \mathrm{de}$ & $56 \mathrm{a}$ & $17 \mathrm{e}$ \\
\hline Leaf (Y) & 60 & - & - & 0.6 & 10 & $25 \mathrm{de}$ & $12 \mathrm{~cd}$ & $63 \mathrm{~b}$ \\
\hline Leaf (Y) & 60 & - & - & 1.2 & 10 & $35 \mathrm{~cd}$ & $10 \mathrm{~cd}$ & $55 \mathrm{bc}$ \\
\hline
\end{tabular}

\footnotetext{
${ }^{2}$ Tissues were sequentially submerged in compounds at concentrations and times as listed and then placed on Woody Plant Medium.
}

${ }^{y}$ Injury assessed as browning or tissue necrosis was determined for only clean cultures, because contamination prevented rating. Healthy cultures were green and undamaged.

${ }^{\times}$Different letters within a column indicate significant differences at $P \leq 0.05$ by Student-Newman-Keuls test.

${ }^{\mathrm{w}} \mathrm{O}$, older expanding leaves, greater than $2 \mathrm{~cm}$, light green color; Y, young leaves, less than $2 \mathrm{~cm}$, yellow green color. 
of auxin applied either continuously or as pulse treatments. For continuous auxin treatment, shoots were placed on half-strength WPM media supplemented with either IAA $(0,10,20$, or $40 \mu \mathrm{M})$ or indole-3-butyric acid (IBA) $(15,30$, or $45 \mu \mathrm{M})$ with $20 \mathrm{~g} \cdot \mathrm{L}^{-1}$ sucrose and $4 \mathrm{~g} \cdot \mathrm{L}^{-1} \mathrm{Gel}-\mathrm{Gro}$. Forty shoots per treatment were used with the experiment repeated twice. For auxin pulse studies, shoots were placed on half-strength $\mathrm{GB}_{5}$ media with either 100 or $150 \mu \mathrm{M}$ IBA for 2 , 5 , or $8 \mathrm{~d}$ and then transferred to the same basal medium in baby food jars. Shoot culture and pulsing was under white fluorescent lights $\left(70 \mu \mathrm{mol} \cdot \mathrm{m}^{-2} \cdot \mathrm{s}^{-1}\right)$ at $25^{\circ} \mathrm{C}$ in a growth room. The percentage of shoots and number of roots per rooted shoot were noted monthly. After 2 months, plantlets were removed from culture medium and roots were washed free of agar. Forty shoots per treatment were used with the experiment repeated twice. Half the plantlets were destructively sampled to determine shoot and root dry weights. Tissues were placed in a drying oven at $70{ }^{\circ} \mathrm{C}$ for $3 \mathrm{~d}$ and then dry weights were recorded. The other half of the plantlets were planted into 72-cell plug trays in a potting mixture of pine bark, cow manure, and sand $(3: 1: 1 \mathrm{v} / \mathrm{v})$ and kept in a $25{ }^{\circ} \mathrm{C}$ growth room under a 16 -h photoperiod $\left(125 \mu \mathrm{mol} \cdot \mathrm{m}^{-2} \cdot \mathrm{s}^{-1}\right)$. The flats were initially covered with clear plastic propagation domes (Humi-dome; Hummert, Earth City, MO) to maintain high humidity and slowly acclimatized over 4 weeks. Two months after transplanting, plants were transferred to the greenhouse.

Additional studies were conducted to evaluate ex vitro rooting. Shoots 2 to $4 \mathrm{~cm}$ long were harvested from cultures in shoot elongation medium. The base of 48 shoots per treatment was dipped in 0,1500 , or 3000 ppm KIBA (indole-3-butyric acid, potassium salt) for $5 \mathrm{~s}$, planted in 72-cell plug trays in the same potting mix used for transplanting of rooted plantlets, and enclosed in the same type of plastic domes for 8 weeks for rooting to take place. Acclimatization was as described earlier. At this time, 24 plants per KIBA treatment were measured for dry weights.

Initiation of culture lines from natural field collections. Leaf material was collected from mature specimens in the wild for initiation of new culture lines from different genotypes during Apr. 2006 when leaves were young and expanding. Field material from 18 genotypes was collected from native populations at Giddens tract and Charles Harrold Preserve in Chandler County, GA, and Bennett property and Fort Stewart in Tattnall County, GA. At the time of collection, shoots were soft, succulent, and new spring growth had just started. Leaves were light green and still expanding. Leaf explants were disinfested using methods established in previous studies, placed on induction media with $10 \mu \mathrm{M}$ TDZ plus $5 \mu \mathrm{M}$ IAA to assess shoot regeneration, then transferred to medium with $25 \mu \mathrm{M} 2 \mathrm{iP}$ for multiplication and elongation as describe previously.

Statistical analyses. Statistical analyses were performed using the GLM procedures and mean separation by the Student-NewmanKeuls test $(P=0.05)$ of SAS (version 8.2 for Windows; SAS Institute, Cary, NC).

\section{Results and Discussion}

Disinfection studies. Obtaining clean cultures from field material was problematic (Table 1). Over $95 \%$ of leaf cultures were contaminated when only ethanol and $\mathrm{NaOCl}$ were used. The addition of a Roccal treatment significantly improved the percentage of clean cultures. However, the most severe sterilization procedure still had over $40 \%$ contamination and most of the uncontaminated cultures exhibited browning and damaged areas. Nonetheless, $19 \%$ of the cultures were successfully disinfested.

Bud tissues similarly exhibited either high contamination rates or severe injury with sterilization. High levels of fungal contamination occurred, which became progressively evident over long periods in culture as buds opened. A successful culture rate of only $8 \%$ was obtained even with the strongest sterilization protocol. Tissues characteristically had brown regions.

In contrast to field material, leaves collected from greenhouse-grown plants had low levels of contamination. Young leaves (less than $2 \mathrm{~cm}$ long) were most effective with $90 \%$ of the cultures showing no contamination when immersed successively for $1 \mathrm{~min}$ in $70 \%$ ethanol, $5 \mathrm{~min}$ in 5\% Roccal, and $10 \mathrm{~min}$ in $0.6 \% \mathrm{NaOCl}$ (Table 1). More severe sterilization methods failed to improve the number of clean cultures and caused greater tissue injury. Older leaves ( $2 \mathrm{~cm}$ long or greater) exhibited lower percentages of successful cultures than young leaves. There were no significant differences in the percentage of successful cultures for the three milder sterilization protocols, which ranged from $35 \%$ to $46 \%$. The most stringent sterilization method caused excessive injury and a lower percentage of successful cultures.

Shoot induction. The effects of induction medium and light conditions were evaluated using buds and leaves of different develop- mental stages (Table 2). Bud explants generally showed no response and were ineffective as an explant source. After 8 weeks culture, bud explants exhibited $8 \%$ and $0 \%$ shoot expansion when maintained under light and dark conditions, respectively. Growth of cultures was restricted to limited expansion of leaf primordia within buds with little or no adventitious bud development observed (Fig. 1A). Tissues exhibited extensive browning and necrosis.

Leaf tissues induced on media with TDZ plus IAA exhibited swelling and cell proliferation within 1 week of culture. Cultures initiated with younger leaves had a faster response than older leaves. Bud primordia were visible after 21 to $28 \mathrm{~d}$ in cultures initiated from young leaves. At 4 weeks, bud-like structures were observed arising from the darkened original explant material (Fig. 1B). Proliferation of structures completely covered the explant material by 8 weeks with shoot clumps from 10 to $20 \mathrm{~mm}$ in diameter obtained (Fig. 1C). Adventitious buds formed on all regions of the leaf explant and occurred on both abaxial and adaxial surfaces. Some limited expansion of shoots was observed. In contrast, older leaves had a much slower regeneration with $40 \mathrm{~d}$ required for visible shoots and buds (data not shown). The best shoot induction (98\%) response occurred with cultures on medium with TDZ plus IAA initiated from young leaves and maintained under a 16 -h photoperiod (Table 2). On this medium, older leaves were still highly regenerable, although at a significantly lower percentage than young leaves. Not only were younger leaves more regenerable, but they also exhibited significantly less browning than older leaves.

TDZ was highly effective in inducing shoot primordia in Georgia plume. TDZ is a phenylurea-derived cytokinin and has potent cytokinin activity in woody plant tissue culture (Huetteman and Preece, 1993). TDZ can promote cell division and differentiation and is reported to induce both organogenesis and somatic embryogenesis. Morphological and histological evaluations of regeneration

Table 2. Effect of plant growth regulators, light conditions, and leaf age on shoot regeneration, callus production, and explant browning in Elliottia racemosa cultures after 8 weeks.

\begin{tabular}{|c|c|c|c|c|c|}
\hline Medium & Explant $^{\mathrm{z}}$ & $\begin{array}{c}\text { Light } \\
\text { condition }^{\mathrm{y}}\end{array}$ & $\begin{array}{c}\text { Shoot regeneration } \\
(\%)\end{array}$ & $\begin{array}{c}\text { Callus } \\
(\%)\end{array}$ & $\begin{array}{c}\text { Browning } \\
(\%)\end{array}$ \\
\hline \multirow[t]{6}{*}{$10 \mu \mathrm{M}$ TDZ $+5 \mu \mathrm{M} \mathrm{IAA}^{\mathrm{x}}$} & Bud & $\mathrm{L}$ & 8 & 0 & 92 \\
\hline & Bud & $\mathrm{D}$ & 0 & 0 & 100 \\
\hline & $\mathrm{Y}$ & $\mathrm{L}$ & $98 \mathrm{a}^{\mathrm{v}}$ & $0 \mathrm{~b}$ & $2 \mathrm{~d}$ \\
\hline & $\mathrm{O}$ & $\mathrm{L}$ & $76 \mathrm{~b}$ & $0 \mathrm{~b}$ & $24 \mathrm{c}$ \\
\hline & $\mathrm{Y}$ & $\mathrm{D}$ & $68 \mathrm{bc}$ & $28 \mathrm{a}$ & $4 \mathrm{~d}$ \\
\hline & $\mathrm{O}$ & $\mathrm{D}$ & $41 \mathrm{~d}$ & $29 \mathrm{a}$ & $30 \mathrm{c}$ \\
\hline \multirow[t]{4}{*}{$25 \mu \mathrm{M} 2 \mathrm{iP}^{\mathrm{w}}$} & $\mathrm{Y}$ & $\mathrm{L}$ & $61 \mathrm{c}$ & $21 \mathrm{a}$ & $18 \mathrm{c}$ \\
\hline & $\mathrm{O}$ & $\mathrm{L}$ & $37 \mathrm{~d}$ & $25 \mathrm{a}$ & $29 \mathrm{c}$ \\
\hline & $\mathrm{Y}$ & $\mathrm{D}$ & $0 \mathrm{e}$ & $28 \mathrm{a}$ & $72 \mathrm{~b}$ \\
\hline & $\mathrm{O}$ & $\mathrm{D}$ & $0 \mathrm{e}$ & $16 \mathrm{a}$ & $84 \mathrm{a}$ \\
\hline
\end{tabular}

${ }^{\mathrm{z}} \mathrm{Y}$, young leaves, less than $2 \mathrm{~cm}$, yellow green; $\mathrm{O}$, older expanding leaves, greater than $2 \mathrm{~cm}$, light green. ${ }^{\mathrm{y}} \mathrm{L}, 16-\mathrm{h}$ photoperiod at $70 \mu \mathrm{mol} \cdot \mathrm{m}^{-2} \cdot \mathrm{s}^{-1} ; \mathrm{D}$, continuous dark conditions.

'With Gamborg's B5 salts.

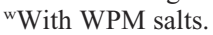

${ }^{v}$ Different letters within a column indicate significant differences at $P \leq 0.05$ by Student-Newman-Keuls test.

$\mathrm{TDZ}=$ thidiazuron; IAA $=$ indole-3-acetic acid; $2 \mathrm{iP}=2$-isopentenyl (adenine). 

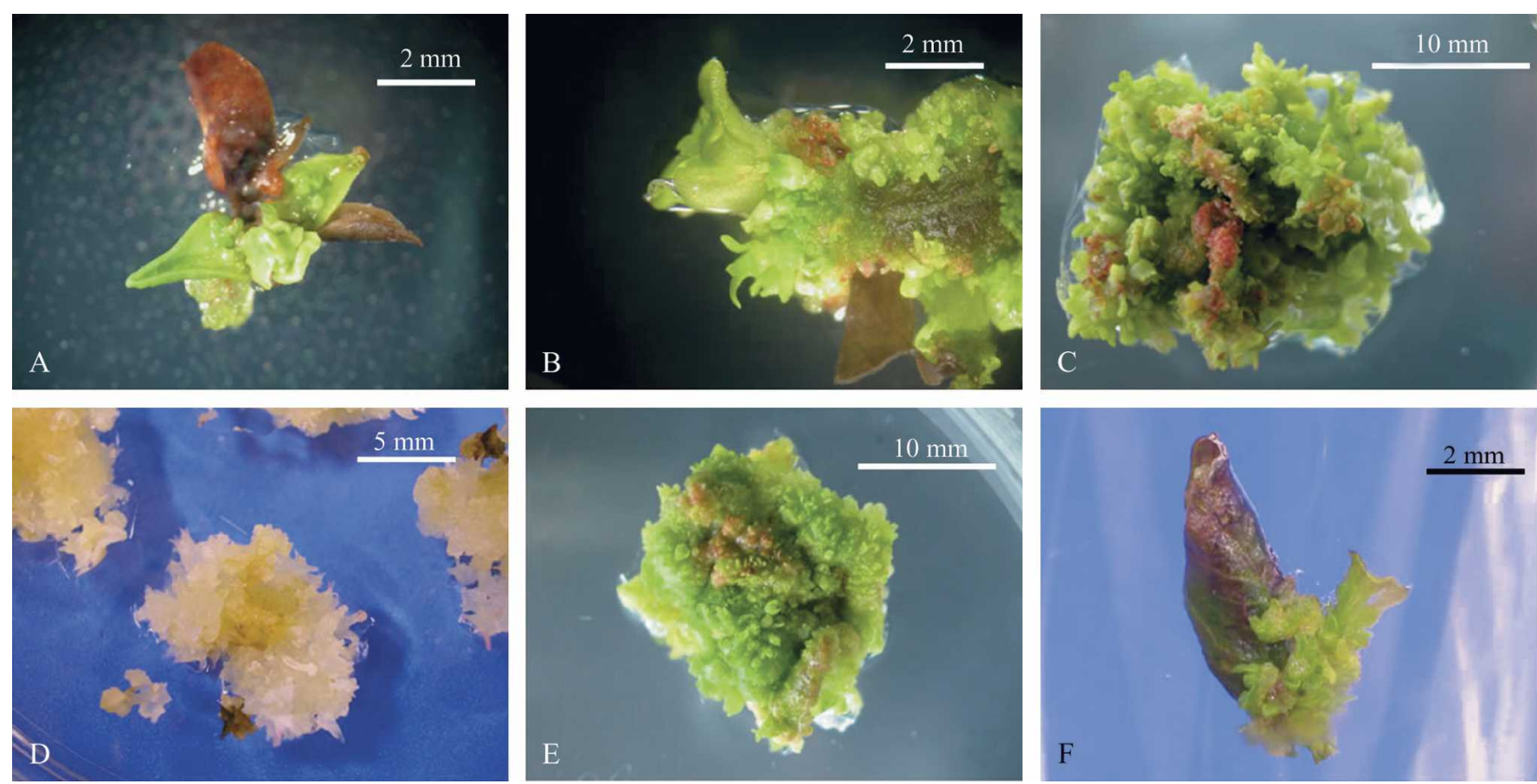

Fig. 1. In vitro shoot organogenesis in Elliottia racemosa. (A) Bud explant after 8 weeks culture on Woody Plant Medium with $25 \mu \mathrm{M} 2 \mathrm{iP}$. (B) Adventitious shoot formation on leaf tissue placed on $10 \mu \mathrm{m}$ thidiazuron (TDZ) plus $5 \mu \mathrm{m}$ indole-3-acetic acid (IAA) under a 16-h photoperiod 4 weeks after explanting. Dark tissue is the original explant. (C) Shoot bud clusters developing on a leaf explant eight weeks after explanting. (D) Leaf explant induced on medium with $10 \mu \mathrm{M}$ TDZ plus $5 \mu \mathrm{M}$ IAA maintained under continuous dark conditions. (E) Leaf explant induced on the same medium as D but maintained under a 16-h photoperiod. (F) Direct shoot organogenesis from leaf tissue cultured on medium supplemented with $25 \mu \mathrm{M} 2 \mathrm{iP}$. Regeneration rates were significantly lower than in cultures induced on media with TDZ plus IAA.

in Georgia plume by Woo and Wetzstein (2008) using the current protocol indicate that shoot organogenesis is induced in actively dividing subepidermal cell layers; embryo-like structures also form, but lack bipolarity and a root pole. Within the Ericaceae, TDZ is reported to be effective in promoting shoot formation when applied at a range of concentrations. On media with 25 $\mu \mathrm{M}$ TDZ, callus formation was induced from blueberry internodes with subsequent shoot production from callus structures (Hruskoci and Read, 1993). Cao and Hammerschlag (2000) achieved shoot regeneration from leaves of several blueberry cultivars using media supplemented with 1 or $5 \mu \mathrm{M}$ TDZ. An efficient regeneration system using leaf explants of cranberry was developed using $10 \mu \mathrm{M}$ TDZ plus $5 \mu \mathrm{M} 2 \mathrm{iP}$ (Qu et al., 2000). Adventitious shoot and bud formation was obtained from hypocotyl segments of lingonberry placed on MS media containing 5 to $10 \mu \mathrm{M}$ TDZ (Debnath, 2003). In contrast, somatic embryogenesis was reported for an Australian Ericaceae (Leucopogon verticillatus) using medium supplemented with $10 \mu \mathrm{M}$ TDZ plus $5 \mu \mathrm{M}$ IAA (Anthony, 2004).

Media containing $2 \mathrm{iP}$ were also effective in inducing shoots in up to $61 \%$ of the cultures (Table 2) with shoot organogenesis from leaf tissue being direct without an intervening callus (Fig. 1F). 2iP has been used to induce shoots from leaf explants in related species such as blueberry (Billings et al., 1988; Callow et al., 1989), cranberry (Qu et al., 2000), and rhododendron (Iapichino et al., 1992). In the current study, shoot regeneration was significantly lower on media with $2 \mathrm{iP}$ than that obtained with TDZ plus IAA (Table 2). Shoots in cultures maintained on 2iP medium for longer than 8 weeks declined, became brown, and nonregenerable. This is in contrast to shoots induced on TDZ plus IAA medium, which continued to proliferate and remained healthy (data not shown).

Leaf cultures maintained under a 16-h photoperiod consistently had higher levels of shoot regeneration than cultures maintained in the dark (Table 2). Cultures induced on media with TDZ plus IAA produced shoots regardless of light condition; however, significantly better shoot regeneration was obtained with correspondingly aged leaves grown in light versus dark. Light was critical for shoot regeneration if $2 \mathrm{iP}$ was used for induction. No shoots were obtained with cultures grown under dark conditions compared with $61 \%$ of the cultures forming shoots from young leaf explants maintained in light conditions.

Culture morphology was markedly affected by photoperiod. Cultures grown under light conditions (Figs. 1C and E) were green and exhibited foliar and shoot development. In cultures maintained under continuous darkness, shoot buds were observed that were white or yellow (Fig. 1D). Dark conditions promoted more callus in cultures induced with TDZ plus IAA. This callus formation did not inhibit proliferation and gave rise to bud and shoot primordia. Light versus dark had no significant effect on callus production in cultures with $2 \mathrm{iP}$, but had marked effects on the browning and decline of cultures. In dark conditions, browning occurred on over $72 \%$ of the cultures. Cultures on TDZ plus IAA in light versus dark conditions had no significant effect on the percentage of cultures exhibiting browning.

Variable results have been reported on the effects of light conditions on adventitious shoot regeneration. Landi and Mexxetti (2006) similarly compared leaf organogenesis in Fragaria under 16-h photoperiod versus continuous dark conditions. In contrast to our results, significantly higher percentages of regenerated shoots and less callus production were obtained under continuous dark versus light conditions. In studies with lingonberry, young leaf tissue maintained in darkness for $7 \mathrm{~d}$ was the best for producing adventitious shoots (Debnath and McRae, 2002). Cao and Hammerschlag (2000) evaluated the effect of light intensity (55 $\mu \mathrm{mol} \cdot \mathrm{m}^{-2} \cdot \mathrm{s}^{-1}$ versus $\left.18 \mu \mathrm{mol} \cdot \mathrm{m}^{-2} \cdot \mathrm{s}^{-1}\right)$ on shoot regeneration from leaf explants in five blueberry cultivars. The number of shoots per explant varied with genotype and was significantly better or inhibited depending on cultivar evaluated.

Studies conducted to evaluate the longterm maintenance of shoot induction cultures on media with different concentrations of plant growth regulators determined that retaining cultures on their original induction medium was most effective. Cultures transferred onto basal media lacking plant growth regulators rapidly declined and turned brown (Fig. 2A), whereas those placed onto media with TDZ plus IAA, at original or 

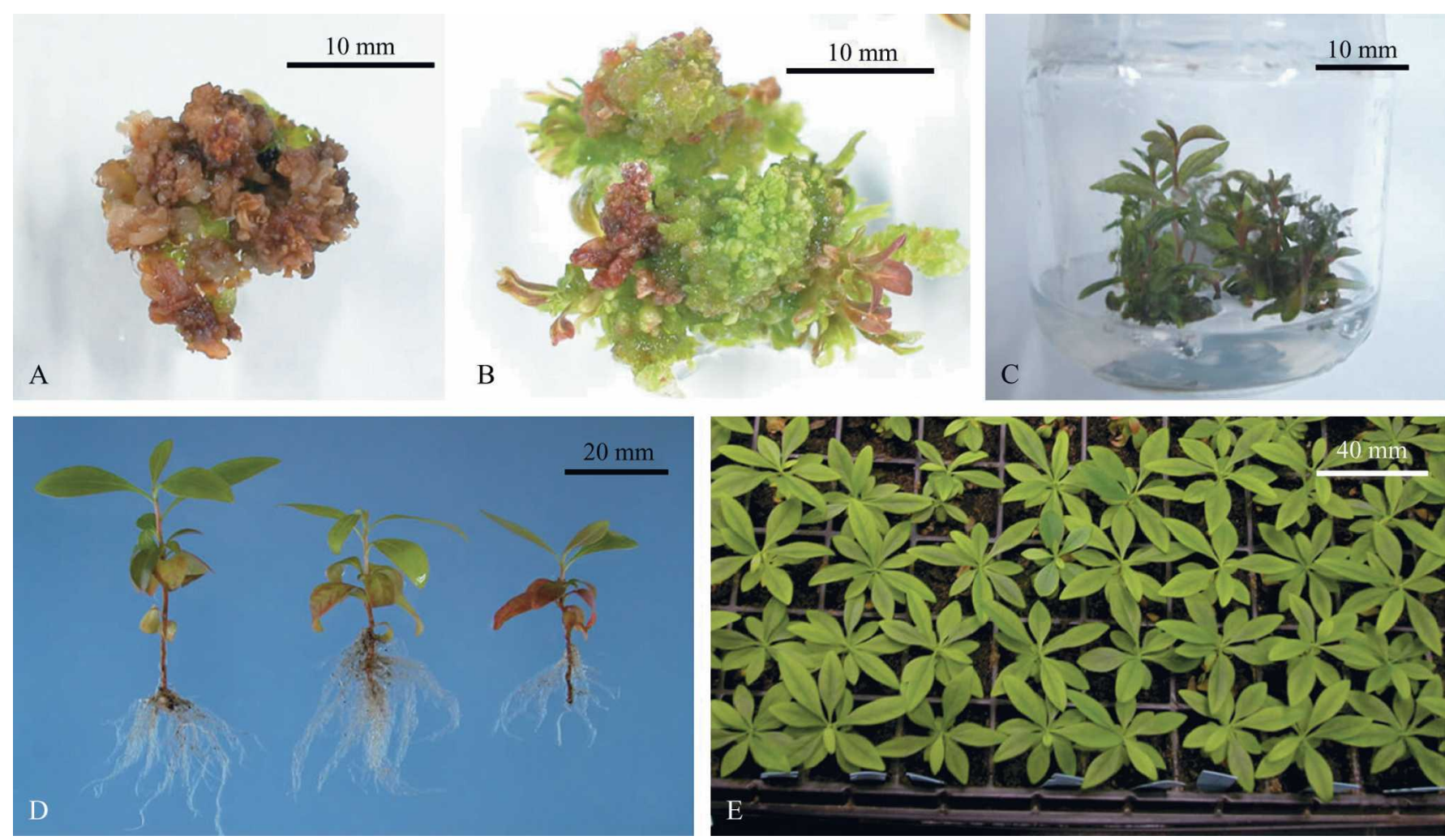

Fig. 2. Maintenance and further development of adventitious shoots. (A) Adventitious shoot bud clumps on basal medium with no plant growth regulators.

(B) Adventitious shoot bud clumps on medium with thidiazuron plus indole-3-acetic acid. (C) Shoot elongation occurring in cultures transferred to a medium with $25 \mu \mathrm{M} 2 \mathrm{iP}$. (D) Shoots showing numerous adventitious roots. (E) Acclimatized plantlets in flats in the greenhouse.

half-strength concentration, exhibited less browning and developed foliar shoot-like structures. For continued proliferation of adventitious shoots, TDZ plus IAA was required in this study. On both TDZ plus IAA treatments, continued proliferation of buds and expansion of shoots were observed (Fig. 2B). Debnath and McRae (2001a) evaluated transferring lingonberry shoot clumps induced on TDZ medium to media with no or lower TDZ $(0.1$ or $1 \mu \mathrm{M})$. Results were similar to that found with Georgia plume, i.e., shoots on basal media turned brown and died. Cultures maintained on media with TDZ remained viable, but failed to elongate. Malabadi et al. (2004) found that although TDZ was efficient for inducing shoot regeneration, its use for longer than 8 weeks resulted in distorted shoots.

Shoot elongation studies. To promote shoot elongation in the current study, proliferating cultures that were initiated on induction medium under either light or dark conditions were transferred to a medium with $25 \mu \mathrm{M} 2 \mathrm{iP}$. This medium was very effective in promoting shoot elongation with the number of elongated shoots influenced by the light conditions during induction. Cultures previously initiated in the light had almost twice as many elongated shoots as dark-induced cultures ( 2.3 versus 5.2 shoots) in 4 weeks. Elongated shoots were clearly visible arising in clumps. At 8 weeks, shoots from cultures initiated in light conditions exhibited further dramatic increases in number (3.4 versus 9.1 shoots in dark and light-initiated cultures, respectively) with shoots attaining heights of up to $5 \mathrm{~cm}$ (Fig. 2C)

TDZ reportedly inhibits shoot elongation in a number of woody species (Huetteman and Preece, 1993). Strategies to overcome this problem include transfer of cultures to a secondary media with a lower concentration of TDZ, a different cytokinin, or no plant growth regulator. Qu et al. (2000) obtained a highly efficient regeneration system using cranberry leaf explants induced on media with $10 \mu_{\mathrm{M}}$ TDZ plus $5 \mu_{\mathrm{M}} 2 \mathrm{iP}$. For elongation of adventitious shoots, cultures were transferred onto a basal medium with no growth regulators. In azaleas, shoots induced with TDZ exhibited improved shoot elongation when transferred to media with lower concentrations of TDZ (Briggs, 1988). In studies of adventitious shoot regeneration with lingonberry leaf explants, stunted shoot development and inhibition of elongation caused by TDZ was overcome by transferring shoot cultures to a shoot elongation medium containing zeatin (Debnath, 2003, 2005). Vijaya Chitra and Padmaja (2005) used a two-stage culture procedure in which leaf explants induced on medium with TDZ were transferred to a secondary medium with 6-benzylamminopurine to promote shoot elongation. They emphasized the importance of double-stage treatments to improve shoot morphogenesis, particularly when TDZ is used to initiate cultures.

Rooting studies. Several attempts to promote and improve rooting were investigated in this study. Strategies for the application of auxin included prolonged or continuous auxin applications in which auxin was incorporated into the rooting medium or pulse treatments in which shoots were treated with high levels of auxin for a few days before transfer to auxin-free medium.

Continuous auxin treatment showed that auxin type and concentration significantly influenced the rooting of shoots (Table 3). At 4 weeks, IAA generally was better than IBA for rooting of Georgia plume shoots and promoted higher percent rooting and root numbers than most IBA concentrations evaluated. Concentration of IAA had no significant effect, with $48 \%$ to $65 \%$ rooting obtained. In contrast, high levels of IBA (45 $\mu \mathrm{M})$ proved to be inhibitory. Callus formed at the base of shoots and no rooting was observed. Substantial amounts of callus formation were reported by Kim et al. (1985) in mulberry shoots rooted with high levels of IBA, which caused poor vascular connections between shoots and adventitious roots. Low levels of exogenous auxin are required for Georgia plume rooting as evidenced in the observation that shoots given no auxin still exhibited $37 \%$ rooting. However, rooting was significantly improved with all auxin applications except for the highest IBA concentration. At 8 weeks, high rooting percentages were obtained, ranging from $\approx 77 \%$ to $95 \%$ on media with IAA (Table 3). Rooting percentages of shoots treated with IBA approached values obtained on shoots placed on IAA medium except for the $45 \mu \mathrm{M}$ IBA treatment, which still had a poor rooting 
Table 3. Effects of continuous applications of various auxins on the in vitro rooting of Elliottia racemosa shoots at 4 and 8 weeks on half-strength Woody Plant Medium.

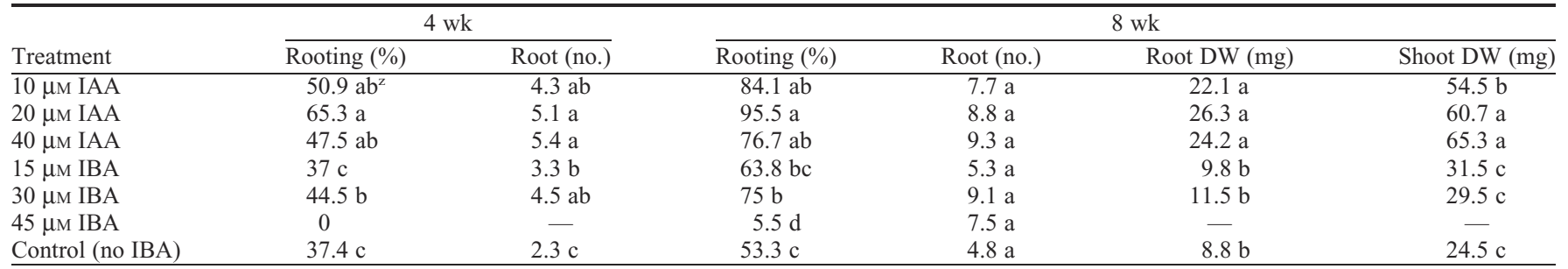

${ }^{2}$ Different letters within a column indicate significant differences at $P \leq 0.05$ by Student-Newman-Keuls test.

$\mathrm{DW}=$ dry weight; IAA = indole-3-acetic acid; IBA = indole-3-butyric acid.

percentage. Although the number of roots was not significantly different among treatments, root and shoot dry weights were two to three times greater in IAA treatments compared with the weights obtained with IBA or control treatments. Continuous exposure of shoots to high levels of auxin can have detrimental effects. Bouza et al. (1992) found that high auxin harmed terminal buds and that plantlets did not grow normally. In addition, increased callus formation can occur under conditions with high levels of auxin. Thus, studies to evaluate short-duration auxin treatments were conducted.

Auxin pulse treatment promoted high levels of rooting with $77 \%$ to $95 \%$ rooting obtained at 4 weeks after transfer to auxinfree media (Table 4). Neither the concentration of IBA nor pulse time of 2 to $8 \mathrm{~d}$ had a significant effect on rooting percentage or root number. Significantly greater root and shoot dry weights were obtained with 5-d pulse treatments compared with pulse treatments of 2 or $8 \mathrm{~d}$. Thus, pulse time appeared to be a more important factor than IBA concentration. Rooting was rapid with pulse treatments and occurred by 4 weeks (Table 4), whereas continuous auxin treatments (Table 3 ) required 8 weeks to obtain comparable rooting percentages.

Pulse applications of auxin have been applied in a number of cases with improved rooting obtained. Rooting was obtained with Paeonia suffruticosa Andr. shoots when cultured on medium supplemented with $75 \mu \mathrm{M}$ IBA for $10 \mathrm{~d}$ followed by transfer onto medium containing activated charcoal with no plant growth regulators (Bouza et al., 1992). Lane and McDougald (1982) evaluated rooting in shoot cultures of five apple cultivars. One recalcitrant cultivar, M9, failed to root with continuous NAA applications, but rooted successfully with a pulse application of NAA followed by transfer onto basal medium.

In additional studies, ex vitro rooting of Georgia plume shoots was evaluated and found to be very effective (Fig. 2D). From $79 \%$ to $88 \%$ rooting was obtained (Table 5) whether or not shoots were treated with KIBA. No significant differences in rooting percentage or root dry weights were observed among KIBA treatments. However, shoot dry weight showed two- to threefold increase when KIBA was applied compared with the control. In vitro rooting protocols have some disadvantages compared with ex vitro methods. Roots differentiated in vitro often lack root hairs and vascular connections (George, 1996). Qu et al. (2000) found that shoots of cranberry, a species related to Georgia plume, rooted easily under both in vitro and ex vitro conditions. Roots regenerated ex vitro were more vigorous and lacked callus formation at the base of cuttings. Ex vitro rooting is simpler and eliminates a tissue culture step. Furthermore, roots should sustain less damage during transplanting compared with in vitro-rooted cultures when plantlets are removed from agar-based medium.

Reports of ex vitro rooting in members of the Ericaceae are variable. Lingonberry was successfully rooted (over $80 \%$ ) using ex vitro methods after shoots were dipped in 8000 ppm IBA (Debnath, 2003; Debnath and McRae, 2002). Over $80 \%$ rooting was obtained in rhododendron shoots after auxin dips. Blueberry shoots rooted well in a mixture of peat and perlite in a mist chamber (Gonzalez et al., 2000). In contrast, Iapichino et al. (1992) reported large differences in rooting response $(0 \%$ to $96 \%)$ that varied with cultivar. Meyer (1982) obtained only $10 \%$ to $20 \%$ rooting with rhododendron shoots placed in media amended with IAA.

Acclimatization and rooting of plantlets under humidity domes were very effective. Plantlets exhibited elongation of shoots soon after transfer to potting mixture (Fig. 2E). Rooted plants from both in vitro and ex vitro rooting studies showed very high rates of survival with over $85 \%$ of plantlets surviving in the greenhouse after 1 month.

Initiation of culture lines from natural field collections. The protocols developed for the production of shoot regeneration from leaf explants were very effective with fieldcollected material from different Georgia plume populations. Proliferating shoot cultures were obtained from 11 of 18 genotypes attempted. Young, actively growing leaf tissue appears to be an important factor for culture initiation. In cases in which successful cultures were not obtained, leaf tissues were damaged or exhibited high levels of contamination. Culture lines from all genotypes established produced numerous adventitious shoots.

\section{Conclusions}

This study reports an efficient regeneration protocol for the micropropagation of Georgia plume, Elliottia racemosa. The method uses leaf tissue as the explant source and is suitable for field-grown material collected from mature specimens. Adventitious shoots are induced on a medium supplemented with $10 \mu \mathrm{M}$ TDZ plus $5 \mu \mathrm{M}$ IAA and then transferred to a shoot elongation medium containing $25 \mu \mathrm{M} 2 \mathrm{iP}$. High rooting frequencies can be obtained under in vitro and ex vitro conditions with over $85 \%$

Table 5. The effect of a KIBA quick-dip on ex vitro rooting and growth of Elliottia racemosa shoots after 8 weeks.

\begin{tabular}{cccc}
\hline KIBA & $\begin{array}{c}\text { Rooting } \\
(\%)\end{array}$ & $\begin{array}{c}\text { Root } \\
\text { DW }(\mathrm{mg})\end{array}$ & $\begin{array}{c}\text { Shoot } \\
\text { DW }(\mathrm{mg})\end{array}$ \\
\hline $0 \mathrm{ppm}$ & $79.2 \mathrm{a}$ & $11.1 \mathrm{a}$ & $11.2 \mathrm{c}$ \\
$1500 \mathrm{ppm}$ & $83.3 \mathrm{a}$ & $12.5 \mathrm{a}$ & $21.8 \mathrm{~b}$ \\
$3000 \mathrm{ppm}$ & $87.5 \mathrm{a}$ & $12.8 \mathrm{a}$ & $33.8 \mathrm{a}$ \\
\hline
\end{tabular}

Different letters within a column indicate significant differences at $P \leq 0.05$ by StudentNewman-Keuls test.

KIBA = indole-3-butyric acid, potassium salt; $\mathrm{DW}=$ dry weight.

\begin{tabular}{|c|c|c|c|c|c|}
\hline PGR & Pulse time (d) & Rooting (\%) & Root (no.) & Root DW (mg) & Shoot DW (mg) \\
\hline \multirow[t]{3}{*}{$100 \mu \mathrm{M}$ IBA } & 2 & $81.1 \mathrm{a}^{\mathrm{y}}$ & $6.1 \mathrm{a}$ & $13.6 \mathrm{~b}$ & $32.9 \mathrm{~b}$ \\
\hline & 5 & $89.2 \mathrm{a}$ & $5.7 \mathrm{a}$ & $18.1 \mathrm{a}$ & $45.3 \mathrm{a}$ \\
\hline & 8 & $86.6 \mathrm{a}$ & $6.1 \mathrm{a}$ & $12.1 \mathrm{bc}$ & $34.7 \mathrm{~b}$ \\
\hline \multirow[t]{3}{*}{$150 \mu \mathrm{M}$ IBA } & 2 & $76.6 \mathrm{a}$ & $5.3 \mathrm{ab}$ & $12.5 \mathrm{~b}$ & $33.4 \mathrm{~b}$ \\
\hline & 5 & $89.6 \mathrm{a}$ & $5.4 \mathrm{ab}$ & $17.1 \mathrm{a}$ & $48.1 \mathrm{a}$ \\
\hline & 8 & $95 \mathrm{a}$ & $5.8 \mathrm{a}$ & $10.4 \mathrm{bc}$ & $33.2 \mathrm{~b}$ \\
\hline Control (no IBA) & 0 & $50 \mathrm{~b}$ & $4.2 \mathrm{~b}$ & $8.9 \mathrm{c}$ & $14 \mathrm{c}$ \\
\hline
\end{tabular}


survival of plantlets transferred to greenhouse conditions. Tissue culture appears to be a promising approach for the propagation and conservation of this rare and threatened plant. Future plans are to conduct studies on reestablishing plants in their native habitats and to regenerate plants from divergent populations to aid in conserving the genetic diversity in this species.

\section{Literature Cited}

Anthony, J.M. 2004. Somatic embryogenesis for mass propagation of Ericaceae-A case study with Leucopogon verticillatus. Plant Cell Tiss. Org. Cult. 76:137-146.

Billings, G.S., C.K. Chin, and G. Jelenkovic. 1988. Regeneration of blueberry plantlets from leaf segments. HortScience 23:763-766.

Bouza, L., B. Sotta, M. Bonnet, M. Jaques, and Y. Arnaud. 1992. Hormone content and meristematic activity of Paeonia suffruiticosa Andr. $\mathrm{cv}$. Madame de Vatry vitro plants during in vitro rooting. Acta Hort. 320:213-216.

Bozeman, J.R. and G.A. Roger. 1983. Final status report in Elliottia racemosa Muhl. Ex Ell., the Georgia plume. U.S. Dept. of the Interior, Fish and Wildlife Serv., Region IV.

Briggs, B.A. 1988. Micropropagation of azaleas using thidiazuron. Acta Hort. 227:330-333.

Callow, P., K. Haghighi, M. Giroux, and J. Hancock. 1989. In vitro shoot regeneration on leaf tissue from micropropagated highbush blueberry. HortScience 24:373-375.

Cao, X. and F.A. Hammerschlag. 2000. Improved shoot organogenesis from leaf explants of highbush blueberry. HortScience 35:945947.

Chafin, L.G. 2007. Field guide to the rare plants of Georgia. The State Botanical Garden of Georgia, Athens, GA.

Debnath, S.C. 2003. Improved shoot organogenesis from hypocotyls segments of lingonberry (Vaccinium vitis-idaea L.). In Vitro Cell. Dev. Biol. Plant 39:490-495.

Debnath, S.C. 2005. Effects of carbon source and concentration on development of lingonberry (Vaccinium vitis-idaea L.) shoots cultivated in vitro from nodal explants. In Vitro Cell. Dev. Biol. Plant 41:145-150.

Debnath, S.C. and K.B. McRae. 2001a. In vitro culture of lingonberry (Vaccinium vitis-idaea L.): The influence of cytokinins and media types on propagation. Small Fruit Rev. 1:3-19.
Debnath, S.C. and K.B. McRae. 2001b. An efficient in vitro shoot propagation of cranberry (Vaccinium macrocarpon ait.) by axillary bud proliferation. In Vitro Cell. Dev. Biol. Plant 37:243-249.

Debnath, S.C. and K.B. McRae. 2002. An efficient adventitious shoot regeneration system on excised leaves of micropropagated lingonberry (Vaccinium vitis-idaea L.). J. Hort. Sci. Biotechnol. 77:744-752.

Elliott, S. 1971. A sketch of the botany of South Carolina and Georgia. Introduction by Joseph Ewan. Hafner Publishing Company, New York [Reprint of the 1821 edition.].

Ewan, J. 1968. William Bartram. Botanical and zoological drawings. Memories Amer. Philosop. Soc. 74:1-180.

Fay, M.F. 1992. Conservation of rare and endangered plants using in vitro methods. In Vitro Cell. Dev. Biol. Plant 28:1-4.

Fordham, A.J. 1969. Elliottia racemosa and its propagation. Arnoldia 29:17-20.

Fordham, A.J. 1991. Elliottia racemosa and its propagation. Arnoldia 51:59-62.

Gamborg, O.L., R.A. Miller, and K. Ojima. 1968 Nutrient requirements of suspension cultures of soybean root cells. Exp. Cell Res. 50:151158.

George, E.F. 1996. Plant propagation by tissue culture. 2nd ed. Parts $1 \& 2$. Exegetics Ltd., Edington, UK

Godt, M.J.W. and J.L. Hamrick. 1999. Population genetic analysis of Elliottia racemosa (Ericaceae), a rare Georgia shrub. Mol. Ecol. 8:75-82.

Gomes, G.A., R. Paiva, P.D. Paiva, and E.J. Santiago. 2003. Plant regeneration from callus cultures of Maclura tinctoria, an endangered woody species. In Vitro Cell. Dev. Biol. Plant 39:293-295.

Gonzalez, M.V., M. Lopez, A.E. Valdes, and R.J. Ordas. 2000. Micropropagation of three berry fruit species using nodal segments from field grown plants. Ann. Appl. Biol. 137:73-78.

Hruskoci, J.D. and P.E. Read. 1993. In vitro shoot regeneration from internode segments and internode-derived callus of blueberry ( $\mathrm{Vacci}$ nium spp.). Acta Hort. 346:127-132.

Huetteman, C.A. and J.E. Preece. 1993. Thidiazuron: A potent cytokinin for woody plant tissue culture. Plant Cell Tiss. Org. Cult. 33:105-119.

Iapichino, G., S. McCulloch, and T.H.H. Chen 1992. Adventitious shoot formation from leaf explants of rhododendron. Plant Cell Tiss. Org. Cult. 30:237-241.
Kim, H.R., K.R. Patel, and T.A. Thorpe. 1985 Regeneration of mulberry plantlets through tissue culture. Bot. Gaz. 146:335-346.

Landi, L. and B. Mexxetti. 2006. TDZ, auxin and genotype effects on leaf organogenesis in Fragaria. Plant Cell Rpt. 25:281-288.

Lane, W.D. and J.M. McDougald. 1982. Shoot tissue culture of apple: Comparative response of five cultivars to cytokinin and auxin. Can. J. Plant Sci. 62:689-694.

Lloyd, G. and B. McCown. 1980. Commercially feasible micropropagation of mountain laurel, Kalmia latifolia, by use of shoot tip culture. Proc. Intl. Plant Prop. Soc. 20:421-427.

Mala, J. and V. Bylinsky. 2004. Micropropagation of endangered species Daphne cneorum. Biol. Plant. 48:633-636.

Malabadi, R.B., G.S. Mulgund, and K. Nataraja. 2004. Efficient regeneration of Vanda coeru$l e a$, an endangered orchid using thidiazuron. Plant Cell Tiss. Org. Cult. 76:289-293.

Meyer, M.M. 1982. In vitro propagation of Rhododendron catawbiense from flower buds. HortScience 17:891-892.

Patrick, T.S., J.R. Allison, and G.A. Krakow. 1995 Protected Plants of Georgia. Georgia Department of Natural Resources, Social Circle, GA.

Pereira, M.J. 2006. Conservation of Vaccinium cylindraceum Smith (Ericaceae) by micropropagation using seedling nodal explants. In Vitro Cell. Dev. Biol. Plant 42:65-68.

Qu, L., J. Polashock, and N. Vorsa. 2000. A highly efficient in vitro cranberry regeneration system using leaf explants. HortScience 35: 948-952.

Seeni, S. and P.G. Latha. 2000. In vitro multiplication and ecorehabilitation of the endangered Blue Vanda. Plant Cell Tiss. Org. Cult. 61:1-8.

Thompson, D. and T.P. Spira. 1991. The reproductive biology of the Georgia plume (Elliottia racemosa) (unpublished report submitted to The Nature Conservancy).

Varadaragan, G.S. 1993. Application of tissue culture techniques to maintain a rare species, Puya tuberose. J. Bromeliad Soc. 43:112-118.

Vijaya Chitra, D.E. and G. Padmaja. 2005. Shoot regeneration via direct organogenesis from in vitro derived leaves of mulberry using thidiazuron and 6-benzylaminopurine. Sci. Hort. 106:593-602.

Woo, S.M. and H.Y. Wetzstein. 2008. Morphological and histological evaluations of in vitro regeneration in Elliottia racemosa leaf explants induced on media with thidiazuron. J. Amer. Soc. Hort. Sci. (in press). 